\title{
ÚJ MÓDSZEREK AZ ONKOHEMATOLÓGIAI BETEGSÉGEK MOLEKULÁRIS DIAGNOSZTIKÁJÁBAN
}

\section{NEW METHODS IN THE MOLECULAR DIAGNOSTICS OF HEMATOLOGICAL MALIGNANCIES}

\author{
Gángó Ambrus', Alpár Donát'², Bödör Csaba ${ }^{3}$ \\ ${ }^{1} \mathrm{PhD}$-hallgató \\ gango.ambrus@med.semmelweis-univ.hu \\ ${ }^{2} \mathrm{PhD}$, tudományos munkatárs \\ alpar.donat@med.semmelweis-univ.hu \\ ${ }^{3} \mathrm{PhD}$, tudományos fómunkatárs \\ bodor.csaba1@med.semmelweis-univ.hu \\ MTA-SE Lendület Molekuláris Onkohematológia Kutatócsoport, I. sz. Patológiai és Kísérleti Rákkutató Intézet, \\ Semmelweis Egyetem, Budapest
}

\begin{abstract}
ÖSSZEFOGLALÁS
Az elmúlt években robbanásszerű fejlődésnek lehettünk tanúi a genetikai vizsgáló módszerek terén, amely magával hozta a daganatok genetikai hátteréről szerzett ismereteink nagyarányú bővülését. Különösen igaz ez a vérképzőszervi daganatok, azaz az onkohematológiai kórképek esetében.

Szinte napról napra ismerünk meg új genetikai eltéréseket, amelyek szerepet játszanak a daganatok kialakulásában, progressziójában, terápiás válaszkészségében és rezisztenciájában. A mutációs célpontok ismeretében lehetőség nyílik a daganat lényegét jelentő eltérések gyógyszeres befolyásolására, a daganatsejtek szelektív gátlására. Ezek a célzott terápiás lehetőségek a legtöbb entitás esetén már elérhetők, és a beteg genetikai eltéréseit figyelembe véve, a hagyományos kemoterápiát kiegészítve vagy akár helyettesítve valódi, személyre szabott terápiás megközelítést nyújtanak. Összefoglaló közleményünkben az onkohematológia molekuláris vizsgálómódszereinek fejlődését és a legújabb technológiákat tekintjük át.
\end{abstract}

\section{ABSTRACT}

In recent years we witnessed unprecedented advances in the field of genomic technologies leading to a rapid expansion of our knowledge on the genetic background of various cancer types. This progress has been particularly pronounced in the field of hematological malignancies. Indeed, novel genetic lesions associated with the pathogenesis, progression and clinical behavior of cancer are still being discovered. Understanding the mutation targets allows development of selective targeted therapies, which are already available in majority of the malignant hematological diseases, and considering the genetic makeup of the patients represent a truly 
personalized therapeutic approach in combination with the standard chemotherapy or even as an alternative for the standard therapeutic protocols. In this review we summarize the advances of molecular diagnostic approaches used in oncohematology with a special focus on the most recent, cutting edge technologies.

Kulcsszavak: molekuláris diagnosztika, daganatkutatás, onkohematológia, célzott terápia, újgenerációs szekvenálás

Keywords: molecular diagnostics, cancer research, oncohematology, targeted therapy, next-generation sequencing

Az elmúlt néhány évben robbanásszerü fejlödés következett be a genetikai vizsgáló módszerek területén, ami magával hozta az onkológia, és különösen az onkohematológia diagnosztikus, prognosztikus és terápiás tárházának nagyarányú bővülését. Több mint egy évtized telt el a Humán Genom Projekt befejezése, a teljes humán genom megismerése óta. Ez a hatalmas léptékủ kutatás igényt támasztott a nagyobb áteresztőképességü, egyszerübb és költséghatékonyabb technológiák kifejlesztésére a DNS-t alkotó bázisok sorrendjének meghatározásához, azaz a szekvenáláshoz. Az egészséges ember genetikai kódjának megfejtése óta a figyelem a betegséggenomok megfejtésére irányul, azzal a céllal, hogy az adott betegség kialakulásában kulcsfontosságú genetikai eltéréseket ismerjünk meg. Mivel a daganatos morbiditás és mortalitás népegészségügyi szempontból kiemelt jelentőséggel bír, a daganatgenomok feltérképezése fontos és sürgető feladat. Az elmúlt években sok ezer fős betegpopulációkon végzett szekvenálással meghatározták a legtöbb szolid daganat (például tüdőrák, vastagbélrák, melanóma) és hematológiai malignitás (különböző leukémiák és limfómák) genetikai összetételét. Ennek jelentősége egyfelől a daganatok biológiájának (kialakulásának, progressziójának, terápiarezisztenciájának) megértése; másfelöl a diagnózisalkotásban, a kórlefolyás becslésében, a hatékony terápia megválasztásában, a kezelés hatékonyságának felmérésében nyújt elengedhetetlen segítséget, és válik részévé a mindennapi patológiai diagnosztikának.

Napjainkra a személyre szabott terápia elérhető közelségbe került, és számos onkohematológiai kórkép esetén már a realitást jelenti. A génállomány eltéréseinek ismeretében racionális gyógyszertervezésre nyílik lehetőség, a célzott gyógyszerekkel a betegség lényegét jelentő genetikai hibát véve célpontként. A daganatok kezelésében a célzott terápia a hagyományos kemoterápiát egészíti ki vagy helyettesíti, és mivel ennek alkalmazása az egyedi genetikai eltérések függvényében történik, valódi, személyre szabott terápiát jelent.

Az onkohematológia a vér, a csontvelö és a nyirokrendszer daganatos betegségeivel foglalkozó tudományág, amely mindig élen járt a daganatos betegségekkel 
kapcsolatos kutatásban, diagnosztikában és az új terápiás lehetőségek bevezetésében. A hematológiai daganatok közé tartozó, körülbelül száz entitás rendkívül heterogén csoportot jelent klinikai és genetikai szempontból is. Két fö csoportjuk a leukémiák (elsődlegesen a csontvelő és a vér betegségei), valamint a limfómák (elsődlegesen a nyirokcsomók betegségei). Az onkohematológiai kórképek között találunk rendkívül agresszív, gyors lefolyású betegségeket (akut leukémiák), amelyek kezelés nélkül néhány hét alatt halálhoz vezethetnek, valamint lassú lefolyású, többször kiújuló betegségeket (egyes limfómák). Kialakulásuk genetikai eltérésekre vezethető vissza, amelyek érinthetik a génállomány kis részét (például egy vagy néhány bázist érintő mutációk egy adott génben), de egyes kromoszómák vagy kromoszómarégiók vesztése, nyerése, áthelyeződése is állhat a háttérben. A szolid tumorokhoz (például tüdőrák, vastagbélrák) képest a hematológiai daganatok hátterében általában kevesebb genetikai eltérést találunk, egy vagy néhány eltérés elegendő az adott kórkép kifejlödéséhez. A szolid tumorokkal szemben a hematológiai daganatok esetében a mintavétel általában egyszerübb. Egyes esetekben (például heveny leukémiák) a leukémiás sejtek nagy számban vannak jelen a perifériás vérben, így egy egyszerü vérvétel elegendő lehet a diagnózis felállításához, amit természetesen tovább pontosítanak egyéb eljárások, például a csontvelö-biopszia. Limfómák esetén általában a daganatos nyirokcsomó biopsziás mintavétele vagy sebészi eltávolítása szolgáltatja a diagnózis felállításához a mintát.

Mivel az egyes kórképek lefolyása, kezelése nagyon eltérő lehet, rendkívül fontos a precíz kórismézés. Az onkohematológiai betegségek diagnosztikája egy komplex, számos modern vizsgálómódszert is magában foglaló algoritmus mentén zajlik napjainkban (Király et al., 2016).

A csontvelő vagy nyirokcsomó szövettani vizsgálata a legtöbb entitás esetében elengedhetetlen. Az alapvető hematoxilin-eozinfestést immunhisztokémia egészíti ki, amely a hasonló morfológiájú sejtek besorolását segíti sejtfelszíni és intracelluláris markerek azonosításával. A sejtfelszíni markerek alapján történő elválasztás az alapja az áramlási citometriának is, amely folyékony minták (vér, csontvelö-aspirátum) sejtösszetételének meghatározására képes rendkívüli pontossággal és érzékenységgel. Mivel a különböző eredetű és fejlődési fázisú sejtek sejtfelszíni markermintázata eltérö, e vizsgálattal ezen sejtek elkülöníthetők egymástól (például egy mintában megadható, hogy vannak-e jelen leukémiás sejtek, és ezek az összes sejt hanyadrészét teszik ki). A morfológián túl nagyon fontos a daganatsejtek genetikai eltéréseinek analízise is, mivel számos aberráció vizsgálata elengedhetetlen a betegség osztályozásában, a kórlefolyás becslésében, valamint a megfelelő terápia megválasztásában. A kromoszómaeltérések (deléciók, nyerések, transzlokációk) vizsgálatára szolgál a hagyományos citogenetika (ún. kromoszómasávozás) és a fluoreszcens in situ hibridizáció (FISH). Az előbbi eljárás, a kariotipizálás előnye, hogy a teljes kromoszómakészletet vizsgálja, 
elözetesen nem várt eltérés is felismerhető lehet. Hátránya, hogy osztódásban lévő sejteket igényel, illetve kisebb kromoszómaeltérések rejtve maradhatnak. A FISH-eljárás során konkrét eltérésekre tervezett fluoreszcens próbák jelzik az eltérés jelenlétét vagy hiányát. A módszer nem igényli, hogy a sejtek osztódásban legyenek, viszont az aberrációspecifikus próbák miatt célzott kérdés feltétele szükséges a vizsgálat előtt. Az említett, hagyományos vizsgálómódszereket kiegészíti a nukleinsav- (DNS, RNS) alapú molekuláris metódusok széles tárháza. A molekuláris eltérések vizsgálata mára a mindennapi diagnosztika részévé vált a legtöbb entitásban, és a korábbi, sejt- és szövetmorfológián alapuló osztályozásokat molekuláris alcsoportok váltották fel a legtöbb hematológiai daganatos betegség esetében.

A molekuláris vizsgálatok nemcsak a diagnosztikában, hanem a prognózis becslésében, a terápia tervezésében és hatékonyságának becslésében is kulcsfontosságúvá váltak napjainkra. A molekuláris daganatkutatás zászlóshajója a hematológia, az elsőként megismert daganatgenom az akut mieloid leukémia (AML) volt, valamint az első, átütő erejű célzott terápiás sikert is a hematológia területén, a krónikus mieloid leukémiában (CML) érték el. Az ismeretek bővülése magával hozza az ehhez szükséges technológiai fejlesztéseket is, amelyek rövid idő alatt a mindennapi gyakorlat részévé válnak, és az újabb felfedezésekkel és technológiai, valamint gyógyszerfejlesztésekkel folytatódik a körforgás. Ez eredményezi azt, hogy az onkohematológia napjainkban és a jövőben is az orvostudomány egyik legdinamikusabban fejlödő ága.

Összefoglaló közleményünkben a hematológia vizsgálómódszereinek fejlódését, valamint a célzott és személyre szabott terápia sikertörténetét a krónikus mieloid leukémián (CML) mint modellbetegségen keresztül mutatjuk be, majd az újabb vizsgálati lehetőségeket ismertetjük egyéb entitások esetében.

A CML a vérképző őssejtből kiinduló daganatos betegség, amely érett fehérvérsejtek (granulociták) túlszaporodásával és éretlen fehérvérsejt-előalakok megjelenésével jár a vérben és a csontvelőben ( $2 A$ és $D$ ábra). A betegek általában középkorúak, kezelés nélkül ötéves túlélés várható az agresszív heveny leukémiás transzformáció miatt. A CML kialakulásáért a 9-es és 22-es kromoszómák közötti reciprok transzlokáció (kromoszómaszakaszok kölcsönös kicserélődése) felelős. Az így kialakuló, az első leírás helyéről elnevezett ún. Philadelphia-kromoszóma tartalmazza a transzlokáció következtében egymás mellé került $B C R$ - és $A B L 1$-géneket. A fúziós génről átíródó fehérjetermék (BCR-ABL1) folyamatosan aktív tirozin-kinázként állandó stimulus alatt tartja a daganatos fehérvérsejtek képzéséért felelős jelátviteli útvonalat. A Philadelphia-kromoszóma klasszikus kariotipizálással, azaz az osztódás meghatározott szakaszában (metafázis) lévő fehérvérsejtek kromoszómakészletének sorba rendezésével és megfestésével azonosítható $(2 B$ ábra), míg a fúziós gén kimutatása a klasszikus módszer szerint fluoreszcens in situ hibridizációval (FISH) történik (a fúziós génre specifikus 
fluoreszcens jelzőmolekula segítségével) (2C ábra). Az 1990-es években a kóros fehérje szerkezetének meghatározását követően, annak ismeretében lehetővé vált a szerkezetre specifikus gátló molekula (a tirozin-kináz-gátló imatinib) megtervezése és klinikai vizsgálata. Az imatinib a tudatos gyógyszertervezés és a célzott terápiák iskolapéldáját jelenti, valamint előfutára a későbbiekben megtervezett és kipróbált számtalan kismolekulájú célzott gátlószernek (1. ábra). Az imatinib rendkívüli hatékonyságú gyógyszer, amelynek köszönhetően a CML-es betegek túlélése mára megközelíti, illetve eléri az egészséges populáció túlélését.

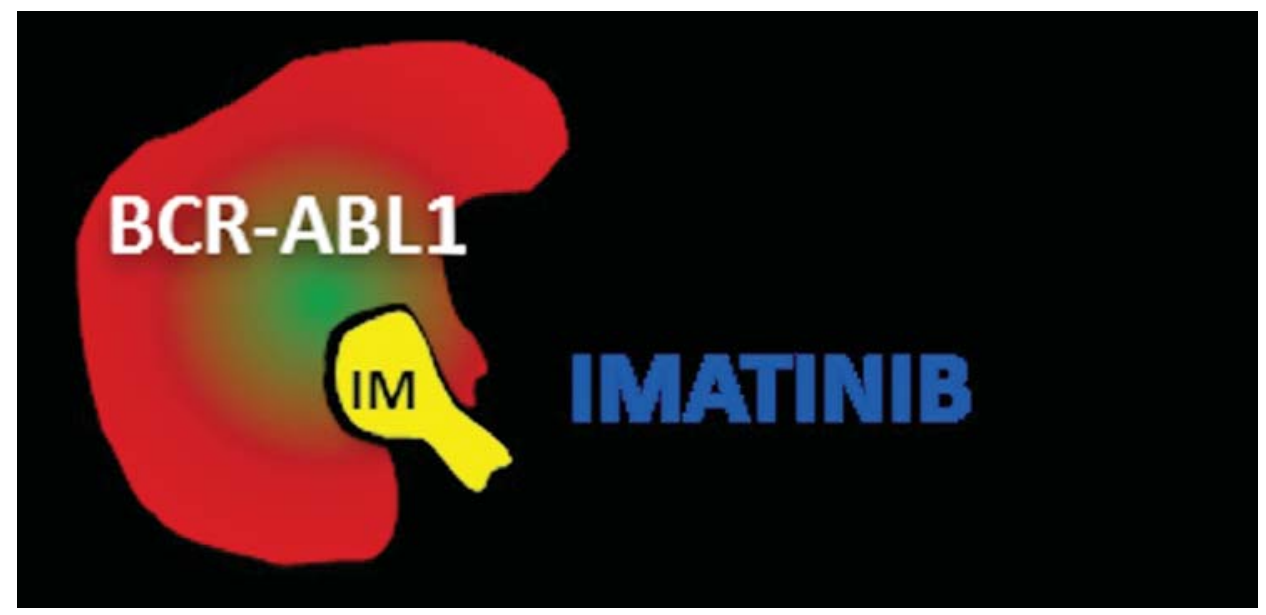

1. ábra. Az imatinib a BCR-ABL1 onkogén hatású tirozin-kinázhoz kötődve gátolja a daganatsejtek szaporodásáért felelős jelátviteli útvonalat (saját szerkesztésủ ábra)

A CML nemcsak a célzott terápiáknak, hanem a kizárólag molekuláris vizsgálatokon alapuló betegkövetésnek és terápiatervezésnek, a valóban személyre szabott molekuláris diagnosztikának és kezelésnek is a modelljét jelenti. Optimális esetben a tirozin-kináz-gátló kezelés hatására csökken a BCR-ABL1 fúziós transzkriptum mennyisége, és a csökkenés mértéke (a molekuláris válasz szintje) alapján pontosan definiálható a kezelés hatékonysága ( $2 E$ ábra). A BCR-ABL1 fúziós transzkriptum szintjének alakulása az onkológiában egyedülálló módon közvetlen terápiás jelentőséggel bír. A fúziós transzkriptum mérése („molekuláris monitorozás") RNS-ből komplementer DNS (cDNS) reverz transzkripcióját követően valós idejü polimeráz láncreakcióval (q-PCR) történik. A folyamat során a felsokszorozott cDNS-mennyiség arányos a kiindulási génexpresszió mértékével, amely fluoreszcenciaintenzitás alapú detektálással kvantifikálható. Ha a beteg meghatározott idő alatt nem éri el a kívánt csökkenést, egyéb tényezők mellett felmerül a terápiaindukált rezisztencia. Ennek hátterében leggyakrabban 
az ABL1-gén pontmutációi (egy-egy nukleotid cseréje) állnak, amelyek meggátolják az imatinib kötődését a fehérjéhez, amely így nem képes gátló funkciójának kifejtésére $(2 F a ́ b r a)$. A rezisztenciamutációk vizsgálata Sanger-szekvenálással történhet, amelynek alapja a fluoreszcensen jelölt, lánctermináló didezoxi-nukleotidok beépülése a szintetizálódó nukleotidláncba, majd detektálásuk kapilláris elektroforézissel történő szeparálás és az egyes ddNTP-k eltérő fluoreszcenciaintenzitása szerint. Rezisztenciamutációk azonosítása esetén újabb generációs

A
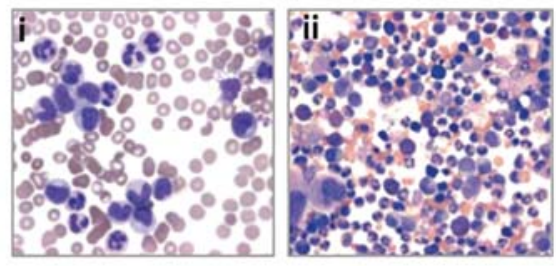

B

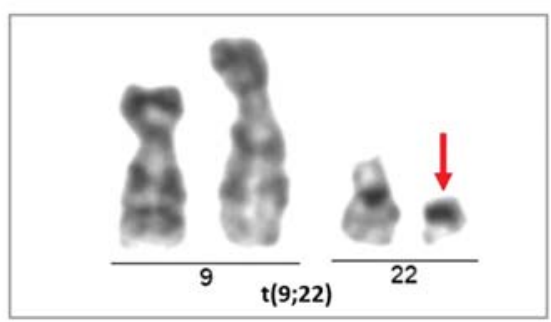

C

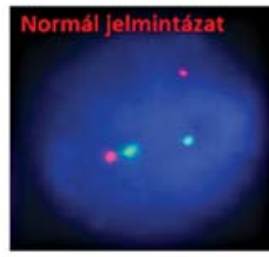

D
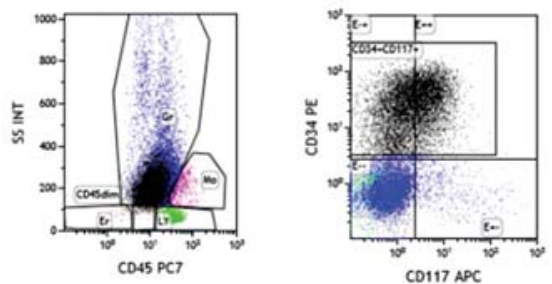

$\mathbf{E}$

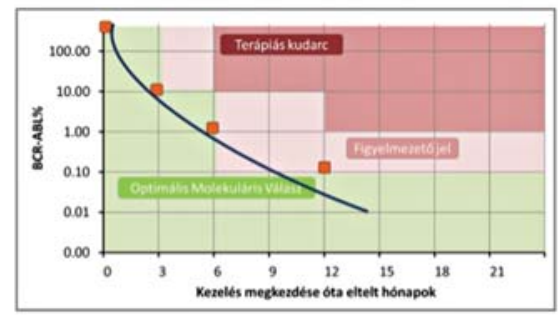

2. ábra. A krónikus mieloid leukémia (CML) komplex diagnosztikai algoritmusához tartozik $(A, i)$ a perifériás vérkenet és $(A$, ii) a csontvelő morfológiájának vizsgálata,

(B) a Philadelphia-kromoszóma kimutatása kariotipizálással, (C) a BCR-ABL1 fúziós gén detektálása fluoreszcens in situ hibridizációval, (D) a sejtarányok azonosítása felszíni markereik alapján áramlási citometriával, (E) a terápiás válasz értékelésére szolgáló összefüggés a BCR-ABL1-expresszió és a kezelés kezdete óta eltelt idő alapján, (F) a Sanger-szekvenálással detektált T315I-rezisztenciamutáció detektálása esetén terápiaváltás szükséges (saját szerkesztésủ ábra) 
tirozin-kináz-gátlók (például dasatinib, nilotinib, bosutinib, ponatinib) is alkalmazhatók az újabb fejlesztések révén, amelyek imatinibrezisztens esetekben is hatékonyak az eltérő kötődési helyüknek és affinitásuknak köszönhetően. Az azonosított rezisztenciamutáció típusa, valamint a beteg társbetegségei meghatározzák, hogy az említett új tirozin-kináz-gátlók közül melyiknek az alkalmazása a legkedvezőbb. Ha a molekuláris monitorozás során a beteg meghatározott időn keresztül nagyon kedvező választ mutat, felmerül a tirozin-kináz-gátló elhagyásának lehetősége is. Ez az ún. kezelés nélküli remisszió (treatment-free remission, TFR) napjaink legizgalmasabb kérdése és lehetősége CML esetén. Ezeket a betegeket a TFR idején még szigorúbban szükséges monitorozni, és a kismértékü fúziós transzkriptum-emelkedésre is figyelmet kell fordítani. A CML a célzott terápiák és a molekuláris vizsgálatok fejlődésének köszönhetően napjainkra egy kiválóan kontrollálható, megszelídített betegséggé vált, ahol már nem(csak) az a kérdés, hogy mivel kezeljünk, hanem az is, hogy a megfelelő mélységü válasz elérését követően hogyan ne kezeljünk. Ez a paradoxon néhány éve még elképzelhetetlen volt, és az onkohematológiai kutatások óriási léptékü fejlődésének köszönhetően vált valós lehetőséggé.

A CML terápiájában tapasztalt áttörés reményt adott a kutatóknak, klinikusoknak és elsősorban a betegeknek, hogy egyéb onkohematológiai kórképek esetén is megismételhető ez a látványos siker. E cél által vezérelve, az elmúlt évek teljes genomszekvenálási tanulmányainak köszönhetően egyre több daganat genomtérképét ismertük meg. Ehhez elengedhetetlennek bizonyult a szekvenálási stratégia fejlesztése, amely az ún. újgenerációs szekvenálás (next generation sequencing, NGS) révén valósult meg. Az NGS a masszív parallel szekvenáló technikák gyüjtőneve, közös jellemzőjük, hogy a Sanger-szekvenáláshoz képest lényegesen nagyobb áteresztőképességủek, érzékenyebbek, idő- és költségtakarékosabbak (3. ábra). Az NGS-technikák révén lehetőség nyílik a teljes génállomány vizsgálatára (whole genome sequencing, WGS), bár az eljárás magas költsége és interpretálási nehézségei (a génállomány 98\%-a fehérjét nem kódoló intronikus szakasz) miatt nem terjedt el. A teljes kódoló régió (exom) vizsgálatára szolgáló WES (whole exome sequencing) értéke a csíravonali eltérések vizsgálatában rejlik, jellemzően az öröklött, ritka, nagyon heterogén genetikai hátterü betegségek esetén. A legelterjedtebb eljárás az onkohematológiai betegségek terén a célzott újraszekvenálás (az ún. génpanelek vizsgálata), amely egy adott kórképre jellemző, néhány tíz vagy száz gén célzott vizsgálatát jelenti (Kuo et al., 2017). Ez történhet egyedileg tervezett génpanelekkel, illetve már rendelkezésre álló, tematikus panelekkel (például a mieloid daganatokban leggyakrabban érintett ötven gén vizsgálatára szolgáló panel). Az NGS munkafolyamatában kiemelt jelentőségủ a DNS- vagy RNS-templát megfelelő előkészítése (koncentrációbeállítás és minőség-ellenőrzés), ez nagyban befolyásolja a további lépések (könyvtárkészités, szekvenálás) sikerességét. A szekvenálás során nyert adatok feldolgozása bioinformatikai algoritmusok se- 
gítségével történik, amelyek egy adott variánsra jellemző lefedettség és a mutációs terhelést jelző variáns allélfrekvencia mellett a mutáció biológiai hatásairól, patogenitásáról is közölnek információt az elérhető adatbázisok alapján. Az NGS-technológia a megfelelő platform alkalmazása mellett a pontmutációk kimutatásán túl inszerciók, deléciók, fúziós transzkriptumok expressziójának, illetve a DNS-metilációjának a meghatározására is alkalmas eljárás.

\section{AAGCGGTTAAGTCAGCTTTGGCAGTGGGCGTGTTGGCAGTGGGCGTAGGT AAGCGGTTAAGTCAGC TGGCAGTGGGCGTGT GGCA - - GGCGTAGGT AAGCGGTTAAGTCAG TAGGCAGTGGGCGT TTGGCAGTGGGCGT CGGTTAAGTCAGCTTTGGC TGGGCGTGTTGGCAGTGGGCGTAGGT AGCGGTTAAGTCAGCTTTGGCAGT GCGTGTTGGCA - - - GGCGTAG CGGTTTAGTCAGCTTTGGCAGTGGGC TTGGCA - - - GGCGTAGGT AAGCGGTTTAGTCAGCTTTGGCAGTGGGCG GTTGGCAGTGGGCGTA GCGGTTAA CAGCTTTGGCAGTGGGCG GTTGGCAGTGGGCGTAGG AAGCGGTTAAGTCAGCTTTGGCAGT GCGTGTTGGCA - - GGCGTAGGT CGGTTAAGTCAGCTTTGGC TGGGCGTGTTGGCAGTGGGCGTAGGT GCGGTTAA CAGCTTTGGCAGTGGGCG GTTGGCA - - GGCGTAGG AAGCGGTTTAGTCAG TTGGCAGTGGGCGT TTGGCAGTGGGCGT AGCGGTTAAGTCAGCTTTGGCAGT GCGTGTTGGCA - . - GGCGTAG CGGTTAAGTCAGCTTTGGCAGTGGGC AAGCGGTTAAGTCAGCTTTGGCAGTGGGCG GCGGTTTA CAGCTTTGGCAGTGGGCG \\ TTGGCAGTGGGCGTAGGT GTTGGCAGTGGGCGTA AAGCGGTTAAGTCAGCTTTGGCAGT GCGTGTTGGCAGTGGGCGTAGGT}

3. ábra. Az újgenerációs szekvenálás során néhány bázispáros fragmentumokból (readek) áll össze a teljes vizsgált DNS-szakasz. Az egy nukleotidpozícióra illeszkedő readek száma határozza meg a lefedettséget. A szürke háttérrel jelzett régiók mutációkat jelölnek, a felső sorban látható a referenciaszekvencia (saját szerkesztésủ ábra)

Az NGS-technológia nagy áteresztőképessége és érzékenysége miatt egyre több hematológiai daganat diagnosztikájában válik fontos vizsgálati eszközzé, amelyek közül kiemelhető az akut mieloid leukémia (AML) példája, egy agresszív lefolyású kórkép, amelyben rendkívül fontos a gyors diagnózisalkotás a megfelelő terápia mihamarabbi megkezdéséhez. Az AML genetikai szempontból nagyon heterogén betegségcsoport, osztályozása molekuláris alcsoportokon alapul (Taylor et al., 2017). A korrekt klasszifikációhoz és rizikóbecsléshez számos kromoszomális és molekuláris eltérés vizsgálatára van szükség, amelyek egyedi vizsgálata időigényes és költséges folyamat a hagyományos technikákkal (kariotipizálás, FISH, Sanger-szekvenálás). Éppen ezért jelent kiváló lehetőséget az AML diagnosztikájában az NGS alkalmazása. Sőt, a terápiás lehetőségek több 
évtizedes stagnálását követően, új célpontokkal szemben ígéretes új gyógyszerek váltak elérhetővé (például az FLT3-gátló midostaurin és az IDH2-gátló enasidenib). Mivel ezek a célzott gyógyszerek csak a megfelelő gének mutációinak jelenlétében alkalmazhatóak, a mutációs státusz néhány napon belüli meghatározása NGS-technológiával elengedhetetlen a megfelelő, személyre szabott terápiához. A technológia az AML-en kívül a krónikus limfocitás leukémia (CLL) célzott terápiájának indikálásában is fontos szerepet játszik. A CLL egy indolens (lassú lefolyású) leukémia, a betegek egy része nem reagál a hagyományos kemoterápiára, és igen kedvezőtlen túlélést mutat. Ennek hátterében a „genom őrzőjének”, legfontosabb tumorszuppresszor génünknek, a TP53-génnek a mutációi állnak. Mivel ma már elérhetőek kismolekulájú, célzott gyógyszerek (ibrutinib, acalab-

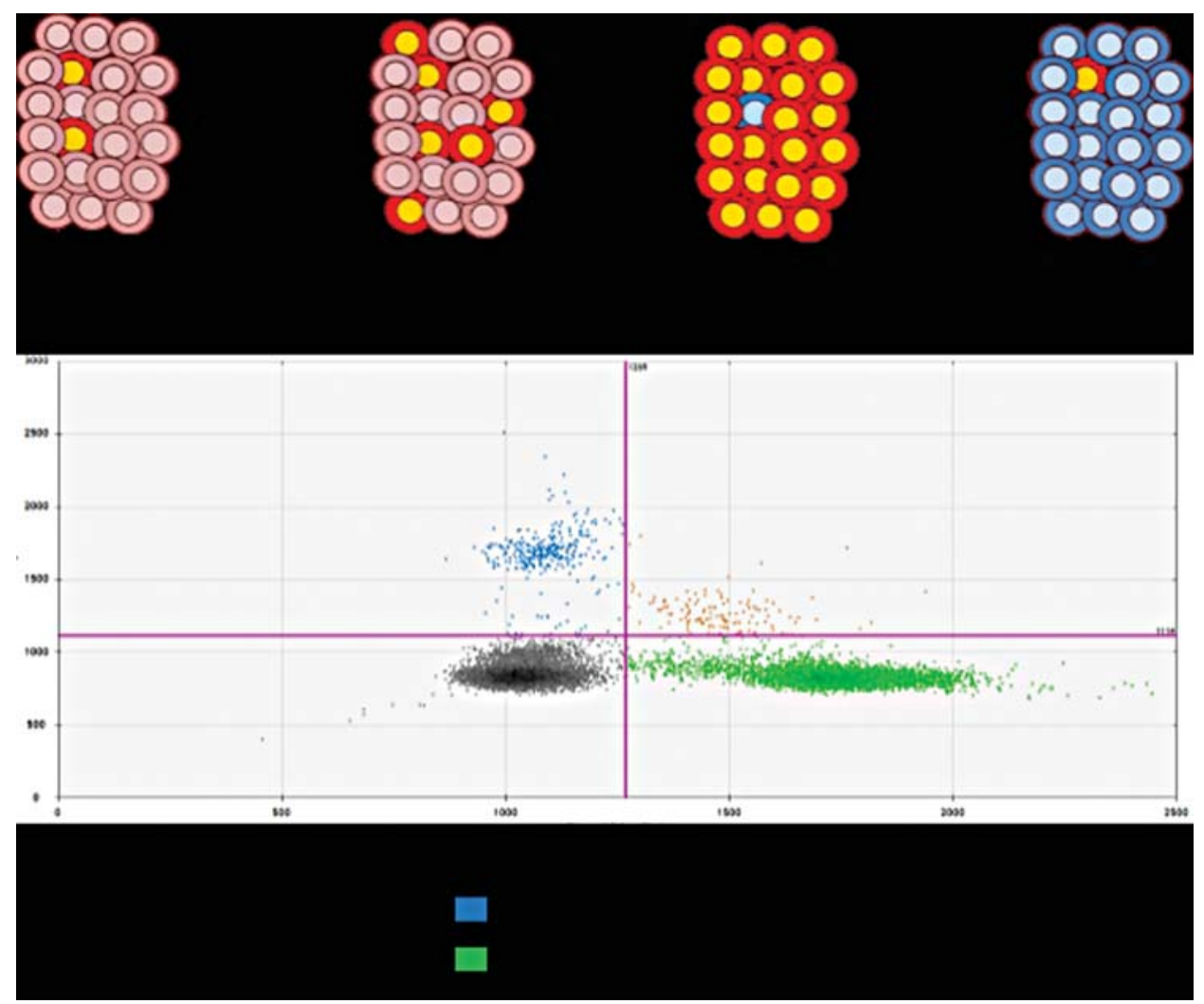

4. ábra. A különbözö kezelési vonalak hatására az adott terápiára rezisztens klónok kiszelektálódnak (eltérő színű korongok), és a betegség újból megjelenik (relapszus). A célzott kezelések által indukált rezisztenciamutációk korai kimutatása nagyon fontos a korai terápiaváltás céljából. Ennek egyik érzékeny módszere a droplet digitális PCR-technika (saját szerkesztésủ ábra) 
rutinib) a TP53-mutációt hordozó betegek számára, rendkívül fontos a mutáció szürése a kezelés megkezdésekor. Mivel az alacsony mutáns allélaránnyal jelen lévő mutáció esetén is megfigyelhető ez a kedvezőtlen kórlefolyás és a kemoterápia hatástalansága, lényeges a mutációk megfelelö érzékeny módszerrel történő kimutatása. A hagyományos Sanger-szekvenálás $20 \%$-os érzékenységénél az NGS sokkal érzékenyebb, szenzitívebb módszer, amely alkalmas az alacsony mutáns allélarányú betegek azonosítására, így a specifikus gátlószerek a beteg rendelkezésére állhatnak. A CML-nél említett imatinibrezisztenciával analóg módon, a CLL-ben is kialakulhat a terápiaindukált ibrutinibrezisztencia. A döntően a $B T K$ - és $P L C G 2$-génekben kialakuló rezisztenciamutációk korai detektálása kulcsfontosságú a terápiás stratégia módosításának szükségessége miatt (4. ábra). Ennek kiváló módszere az NGS-technológia, illetve a később említendő digitális PCR-metodika is.

Az NGS-technológián túl további ígéretes, szenzitív és sokrétủ módszert jelent a digitális PCR-technika. A konvencionális PCR-rel szemben, ahol a teljes templát amplifikációja egy reakciótérben (leggyakrabban $200 \mu$ lérfogatú PCR-csőben) zajlik, a digitális PCR során a kiindulási nukleinsav-molekulák külön reakcióterekben (akár több tízezer kompartmentben) amplifikálódnak, és egy-egy reakciótérben mindössze egy vagy néhány DNS-molekula található. A kompartmentképzés elérhetö többek között ún. „,microfluid” chip technikával, illetve az egyre nagyobb teret hódító droplet digitális PCR-(ddPCR) módszerrel. Manuális vagy automatizált dropletképzést követően olaj-víz emulzióban zajlik az amplifikáció, amely így hatékonyabb és szenzitívebb a hagyományos PCR-eljárásnál. A módszer előnye a valós idejü PCR-rel szemben, hogy abszolút kvantifikációt tesz lehetővé belső kontrollgén (ún. háztartási gén) amplifikációja nélkül. A módszer kiválóan alkalmas pontmutációk, egyes inzerciók és deléciók célzott kimutatására. Az NGS-technikával szemben a módszer ismeretlen eltérések azonosítására nem alkalmas, viszont ismert molekuláris célpontok detektálása (például JAK2 V617F, $B R A F$ V600E) akár $10^{-4}$ érzékenységgel is kivitelezhető.

A ddPCR a szenzitivitásánál fogva alkalmas továbbá minimális reziduális betegség (MRD) kimutatására, folyadék- (liquid) biopsziás mintákból keringő sejtmentes DNS- (cfDNS) alapú vizsgálatok elvégzésére, illetve egysejtanalízisre is. Ez utóbbi felhasználási terület az egyes daganatsejtek genetikai összetételének meghatározásával lehetőséget nyit az intratumorális genetikai heterogenitás vizsgálatára is. A szolid tumorokban nagy népszerüségnek örvendő liquid-biopsziás mintákon alapuló analízisek a különböző limfómáknál is relevánsak lehetnek, ahol a későbbi relapszusok esetén már problémába ütközik az ismételt mintavétel, így nagy jelentősége lehet ezeknek a vizsgálatoknak, ugyanis a cfDNS reprezentálja a teljes tumor heterogenitását, és alkalmas lehet a betegség nyomon követésére, a relapszusok előrejelzésére, valamint a terápiás stratégia módosításához szükséges információ megszerzésére (Scherer et al., 2017). 
A harmadik évezredben tanúi voltunk és vagyunk egy gyökeres átalakulásnak a hematológiai daganatok terén. A kórképek diagnosztikája, osztályozása, rizikóbecslése, terápiája és ennek monitorozása is molekuláris alapokra helyeződött. Ezt a technológiák gyors fejlődése, a felgyorsult gyógyszerfejlesztés tette lehetövé. Mára a mindennapi gyakorlat részét jelentik a legkorszerübb, nagy áteresztőképességủ és érzékenységủ molekuláris eljárások is. Figyelembe véve a tudomány és a gyógyszerfejlesztés irányvonalait, folyamatosan tárulnak elénk újabb és újabb ismeretek. Mindezek által a hagyományos eljárások talaján nyugvó, de az új, innovatív technológiákból építkező, molekuláris alapú diagnosztikus és kezelési megközelítés további bővülése várható a hematológiai daganatok terén.

\section{TÁMOGATÁSI FORRÁSOK}

A kézirat elkészülését a Nemzeti Kutatási, Fejlesztési és Innovációs Hivatal NVKP 16-1-2016-0004 és KH 17/126718 pályázatai, a Magyar Tudományos Akadémia Lendület programja (LP95021), valamint a Magyar Tudományos Akadémia Bolyai János Kutatási Ösztöndíja és az Emberi Erőforrások Minisztériuma által meghirdetett Új Nemzeti Kiválósági Program Bolyai+ ösztöndíja támogatta.

\section{IRODALOM}

Király P. A. et al. (2016): Az onkohematológia molekuláris diagnosztikai vizsgálómódszereinek alapjai. Magyar Onkológia, 60, 88-98.

Kuo, F. C. et al. (2017): The Relative Utilities of Genome-wide, Gene Panel, and Individual Gene Sequencing in Clinical Practice. Blood, 130, 433-439. DOI: 10.1182/blood-2017-03-734533, http://www.bloodjournal.org/content/130/4/433.long?sso-checked=true

Scherer, F. et al. (2017): High-throughput Sequencing for Noninvasive Disease Detection in Hematologic Malignancies. Blood, 130, 440-452. DOI: 10.1182/blood-2017-03-735639, http://www. bloodjournal.org/content/130/4/440.long

Taylor, J. et al. (2017): Diagnosis and Classification of Hematologic Malignancies on the Basis of Genetics. Blood, 130, 410-423. DOI: 10.1182/blood-2017-02-734541, http://www.bloodjournal. org/content/130/4/410.long 